\title{
PERAN MEDIASI KEPUASAN KERJA PADA GAYA KEPEMIMPINAN TRANSFORMASIONAL TERHADAP KINERJA KARYAWAN TOYOTA AUTO 2000 DENPASAR
}

\author{
I Made Adnyana Putra 1 \\ Ida Bagus Ketut Surya ${ }^{2}$ \\ ${ }^{1,2}$ Fakultas Ekonomi dan Bisnis Universitas Udayana (Unud), Bali, Indonesia \\ email: madeadnyanaputra96@gmail.com
}

\begin{abstract}
ABSTRAK
Hasil wawancara karyawan memperoleh permasalahan dalam perusahaan kemampuan prestasi kinerja karyawan menurun dilihat dari tidak tercapainya target penjualan karyawan yang ditetapkan oleh perusahaan, ini dapat disebabkan oleh kurangnya kinerja karyawan dalam memberikan pelayanan terhadap konsumen. Terdapatnya karyawan sedang bermain handphone (alat komunikasi) disaat jam bekerja. Atasan terlalu arogan atau mematok target yang terlalu tinggi. Karyawan yang tidak puas dengan bonus diberikan oleh atasan, sehingga karyawan berharap atasan untuk meningkatkan jumlah bonus yang diterima. Penelitian dilakukan di Toyota Auto 2000 Denpasar sebanyak 107 pekerja dengan metode sampel jenuh, dikumpulkan melalui kuesioner menggunakan teknik analisis statistik deskriptif, analisis jalur dan statistik inferensial. Hasil penelitian menunjukkan bahwa kepemimpinan transformasional berpengaruh positif dan signifikan terhadap kinerja karyawan. Kepemimpinan transformasional berpengaruh positif dan signifikan terhadap kepuasan kerja. Kepuasan kerja berpengaruh positif dan signifikan terhadap kinerja karyawan. Kepuasan kerja secara positif dan signifikan memediasi pengaruh kepemimpinan transformasional terhadap kinerja karyawan.
\end{abstract}

Kata kunci : Gaya Kepemimpinan Transformasional, Kepuasan Kerja, Kinerja Karyawan.

\begin{abstract}
The employee performance capabilities decreased seen from not achieving employee sales targets, this can be caused by a lack of employee performance in providing services to consumers. There are employees using mobile devices during work period. The boss is too arrogant or sets targets that are too high. Employees who are not satisfied with the bonus that are given, so that employees expect the increase of bonus received. The study was conducted at Toyota Auto 2000 with 107 workers using saturated sample method, collected through a questionnaire using descriptive statistical analysis techniques, path analysis and inferential statistics. The results showed that transformational leadership had a positive and significant effect on employee performance. Transformational leadership has a positive and significant effect on job satisfaction. Job satisfaction has a positive and significant effect on employee performance. Job satisfaction is positively and significantly mediates the effect of transformational leadership on employee performance.

Keywords: Transformational Leadership, Job Satisfaction, Employee Performance.
\end{abstract}




\section{PENDAHULUAN}

Perusahaan dalam melaksanakan kegiatannya harus mampu mempertahan daya saing tinggi untuk kelangsungan hidupnya seperti perusahaan bergerak dibidang jasa (layanan) harus berusaha untuk mencapai tujuan perusahaan. Salah satu hal yang harus diperhatikan bersama yaitu sumber daya manusianya, karena karyawan yang memiliki kualitas tinggi bagi perusahaan adalah sebagai faktor penentu keberhasilan dalam perusahaan. Sumber daya manusia yang berkualitas merupakan salah satu kekuatan yang dimiliki oleh setiap organisasi untuk mencapai tujuan yang diharapkan organisasi.

Setiap organisasi harus mampu mengembangkan dan meningkatkan organisasinya dengan mengadakan berbagai cara yang tepat dan tersusun dalam program untuk meningkatkan kinerja karyawan. (Ardana et al., 2012:3) menyatakan sumber daya manusia merupakan harta atau aset yang paling berharga dan paling penting yang dimiliki oleh suatu organisasi atau perusahaan, karena keberhasilan suatu organisasi atau perusahaan sangat ditentukan oleh unsur manusia.

Dwipayana (2016) menyatakan sumber daya manusia sangat penting di dalam menunjang kemajuan organisasi, untuk itu sudah seharusnya kinerja karyawan diperhatikan secara layak dan adil, sehingga mereka dapat melaksanakan tugas dengan sungguh-sungguh dan penuh tanggung jawab.

Di lingkungan bisnis yang terus meningkat saat ini, kinerja karyawan yang tinggi adalah tujuan utama dari sebagian besar organisasi agar dapat mendorong perusahaan untuk beradaptasi dengan lingkungan pasar yang penuh persaingan. Bagaimana cara memperoleh, mengelola dan melaksanakan kinerja terbaik dalam suatu organisasi merupakan salah satu kunci keberhasilan organisasi untuk dapat tumbuh, berkembang dan memiliki keunggulan kompetitif.

Yusuf (2014) menyatakan bahwa kinerja adalah hasil kerja yang dapat dicapai oleh seseorang atau kelompok orang dalam suatu organisasi sesuai dengan wewenang dan tanggung jawab masing-masing.

Gupta (2013) menjelaskan bahwa perusahaan membutuhkan karyawan yang mampu bekerja lebih baik dan lebih cepat, sehingga diperlukannya karyawan yang mempunyai kinerja (job performance) yang tinggi. Sehingga kinerja yang efektif dan efisien, perusahaan harus mampu mengelola sumber daya manusia dengan baik serta mempertahankan kinerja karyawan terbaiknya yang memiliki komitmen yang tinggi terhadap perusahaan.

Suharnomo \& Subakti (2013) menyatakan kinerja menjadi tolak ukur yang dilakukan oleh perusahaan untuk mengukur sejauh mana karyawan dapat mengembangkan tugas yang mereka emban dan bagaimana ada suatu kemajuan yang dialami oleh perusahaan kedepannya. Namun, tidak semua karyawan yang dipekerjakan dalam perusahaan mempunyai kemampuan dan kualitas yang sama dalam penyelesaian tugasnya, karena mengingat kemampuan sumber daya manusia yang dimiliki berbeda-beda. Faktor kinerja karyawan menjadi hal penting diperhatikan karena kinerja karyawan akan menjadi masalah serius bagi perusahaan sehingga dapat mempengaruhi tinggi rendahnya suatu pelayanan.

Faktor terjadinya hasil kinerja karyawan menurun dikarenakan adanya ketidaknyamanan dalam sebuah pekerja, upah yang minim, lingkungan perusahaan, 
keahlian yang tidak mendukung dan juga ketidakpuasan dalam pekerja. Ketidakpuasan menjadi penyebab munculnya masalah-masalah dalam organisasi maupun perusahaan seperti kemangkiran, konflik atasan dengan pekerja, tingkat absensi yang tinggi, adanya pemogokan dan perputaran karyawan.

Simamora (2008:15) menjelaskan kinerja dipengaruhi oleh tiga faktor yaitu: faktor individual (kemampuan dan keahlian, latar belakang, demografi), faktor psikologi (persepsi, attitude, personality, pembelanjaan, motivasi) dan faktor organisasi (sumber daya, kepemimpinan, penghargaan, hubungan kerja, struktur, dan desain pekerjaan).

Toyota Auto 2000 Denpasar merupakan perusahaan yang memperkerjakan sumber daya manusia bergerak dibidang jasa penjualan, perawatan dan perbaikan kendaraan toyota serta menyediakan suku cadang asli Toyota. Pada Toyota Auto 2000 Denpasar memperkerjakan 107 karyawan dengan 27 departemen yang memiliki tujuan untuk dapat meningkatkan kualitas dan pelayanan bagi para peminat toyota dalam persaingan bisnis.

Toyota Auto 2000 Denpasar merupakan perusahaan yang berfilosofi dalam hal mengutamakan kepuasan para konsumennya dengan memperkerjaan sumber daya manusia di dalam seperti jasa penjualan kepada orang lain serta perawatan dan perbaikan kendaraan (service).

Kepercayaan dari para konsumennya mengenai kualitas layanan dan service kendaraan yang diberikan merupakan hal yang sangat diutamakan oleh dealer, agar dapat meningkatkan nama perusahaan Toyota Auto 2000 Denpasar di Bali. Oleh sebab itu, Toyota Auto 2000 Denpasar perlu mendapatkan dukungan dari berbagai pihak, seperti: manajemen dan sumber daya manusia.

Hasil wawancara awal pada 10 orang karyawan memperoleh permasalahan dalam perusahaan seperti: terdapat kemampuan prestasi kinerja karyawan menurun di lihat dari tidak tercapainya target penjualan karyawan yang ditetapkan oleh perusahaan, ini dapat disebabkan oleh kurangnya kinerja karyawan dalam memberikan pelayanan terhadap konsumen. Karyawan tidak optimal dalam memasarkan produk perusahaan, sehingga tidak optimalnya dalam bekerja.

Terdapatnya karyawan sedang bermain handphone (alat komunikasi) disaat jam bekerja untuk mencari informasi lowongan pekerjaan ditempat lain, sehingga karyawan belum bisa berinisiatif dalam mempergunakan waktu jam istirahat untuk mencari konsumen baru dalam memasarkan produk yang ditawarkan.

Hal ini menunjukan indikasi adanya masalah terhadap kinerja karyawan sehingga terkesan lamban dan malas dalam bekerja. Ketidakberhasilan perusahaan di dalam memperhatikan kinerja karyawan lebih lanjut dalam jangka waktu panjang akan berdampak kepada pihak manajemen serta produktivitas perusahaan.

Pambudi et al. (2016) menyatakan peran kepemimpinan dalam suatu perusahaan sangat menentukan keberhasilan suatu perusahaan. Kepemimpinan berpengaruh kuat kepada kehidupan organisasi karena sebagai penentu arah dan tujuan organisasi dalam menghadapi perkembangan zaman yang semakin maju dan persaingan yang semakin ketat. Diantara beberapa macam gaya kepemimpinan salah satu yang lebih tepat untuk mempengaruhi kinerja karyawan adalah gaya kepemimpinan transformasional. 
Hasil penelitian yang dilakukan oleh Ruyatnasih et al. (2013) menyatakan bahwa gaya kepemimpinan berpengaruh positif dan signifikan terhadap kinerja karyawan. Serta penelitian Suharnomo \& Subakti (2013) menyatakan kepemimpinan transformasional dapat mempengaruhi variabel kinerja karyawan. Sehingga kepemimpinan transformasional dianggap paling cocok dari sekian banyak model kepemimpinan yang ada.

Muizu (2014) menyatakan semakin baik penerapan kepemimpinan, maka akan semakin optimal pencapaian kinerja karyawan. Hubungan yang positif antara pemimpin dan bawahannya akan mendukung semua aspek di dalamnya termasuk kinerja dan motivasi para karyawannya yang tentu akan memiliki dampak yang baik terhadap kinerja dari perusahaan secara menyeluruh.

Kepemimpinan transformasional adalah pemimpin menciptakan visi, lingkungan dan memberikan motivasi kepada bawahan untuk berprestasi. Implikasinya bawahan akan merasa kagum, percaya, dan berkomitmen pada pimpinan. Perusahaan yang ingin meningkatkan kinerja karyawannya dapat menerapkan konsep kepemimpinan transformasional sebagai kemampuan yang dimiliki seorang pemimpin untuk mempengaruhi anak buahnya, sehingga mereka akan percaya, meneladani, dan menghormatinya (Paracha et al., 2012).

Pemimpin transformasional memiliki visi dan kemampuan berinteraksi dengan baik kepada karyawan, sehingga dapat memotivasi karyawan dalam mewujudkan visi dan misi perusahaan. Masalah kepemimpinan yang dialami saat ini pada perusahaan dimana atasan terlalu arogan atau mematok target penjualan yang terlalu tinggi, sehingga jarang memberikan solusi yang tepat pada permasalahan yang dialami karyawan.

Jika ingin ditingkatkan hasil penjualan karyawan harus memerlukan peran figur atasan yang dapat memberikan solusi dan pengembangan potensi dalam bekerja dengan baik sehingga target penjualan yang ditetapkan perusahaan tercapai. Ada rasa kurang percayanya karyawan terhadap atasan dan kurangnya rasa hormat karyawan dengan atasan dalam melaksanakan pekerjaan.

Hasil penelitian dari Atmojo (2012) dan Nur Insan et al. (2013) menyimpulkan kepemimpinan transformasional memiliki pengaruh positif dan signifikan pada kepuasan kerja. Dengan demikian sukses atau tidaknya karyawan dalam prestasi kerja juga dapat dipengaruhi oleh gaya kepemimpinan yang diterapkan oleh atasannya. Hal inilah yang menunjukkan kepemimpinan transformasional memberikan dampak positif pada kepuasan kerja karyawan.

Kepuasan kerja sangat penting diciptakan dalam perusahaan, karena tanpa adanya kepuasan kerja maka kinerja karyawan dalam perusahaan tidak berjalan dengan maksimal. Kepuasan kerja adalah salah satu faktor yang dapat mempengaruhi kinerja karyawan, kepuasan kerja adalah sikap emosional positif seseorang terhadap berbagai aspek pekerjaannya (Cemal et al., 2012). Penelitian dari Changgriawan (2017) menyatakan kepuasan kerja berpengaruh signifikan terhadap kinerja karyawan. Serta penelitian dari Arthawan (2017) menyatakan kepuasan kerja berpengaruh positif dan signifikan terhadap kinerja karyawan.

Rosario (2012) mengungkapkan karyawan yang merasa puas senantiasa akan bekerja lebih optimal dengan penuh kesadaran tanpa paksaan, bahkan Samaneh et al. (2012) berpendapat bahwa organisasi yang memiliki karyawan yang merasa 
lebih puas cenderung lebih efektif bila dibandingkan dengan organisasi yang memiliki karyawan yang kurang puas. Kepuasan kerja penting ditingkatkan karena dapat memberikan keuntungan bagi karyawan maupun perusahaan itu sendiri dalam mencapai efektifitas kerja (Tugba \& Tabancali, 2012).

Masalah kepuasan kerja yang dialami perusahaan saat ini dilihat karyawan yang tidak puas dengan bonus diberikan oleh atasan, sehingga karyawan berharap atasan untuk meningkatkan jumlah bonus yang diterima. Tidak sesuainya gaji yang diterima dengan beban kerja yang dijalankan berbeda, namun gaji yang diterima sama. Kepuasan kerja karyawan menurun dilihat pada tidak tercapainya target penjualan yang ditetapkan perusahaan yakni sama jumlahnya dari waktu ke waktu, sehingga ini menjadi masalah yang mengakibatkan karyawan ingin keluar dari perusahaan.

Karyawan yang puas akan cenderung menjadi seorang pekerja yang produktif yang berkontribusi terhadap penciptaan budaya kerja yang tepat di dalam organisasi. Karyawan yang memiliki kepuasan kerja juga memiliki perasaan positif terhadap pekerjaan yang menjadi tanggung jawab karyawan tersebut. Maka itu kepuasan karyawan harus diperhatikan secara serius oleh atasan perusahaan karena penentu kinerja karyawan dalam organisasi. Hasil penelitian yang dilakukan Lestari (2018) menyimpulkan kepuasan kerja mampu memediasi secara parsial gaya kepemimpinan transformasional terhadap kinerja karyawan.

Teori yang digunakan dalam penelitian ini adalah Teori Hirarki Kebutuhan yang dicetuskan oleh Abraham Maslow. Teori hirarki kebutuhan menitik beratkan pada pemenuhan kebutuhan dasar manusia secara fisik, lalu berlanjut pada kebutuhan yang bersifat external yang berhubungan dengan dunia luar secara vertikal maupun horizontal dalam bingkai hirarki organisasi (Iskandar, 2016)

Ruyatnasih et al. (2013) menyatakan bahwa gaya kepemimpinan berpengaruh positif dan signifikan terhadap kinerja karyawan. Penelitian yang dilakukan oleh Suharnomo \& Subakti (2013) menyatakan kepemimpinan transformasional dapat mempengaruhi variabel kinerja karyawan. Semakin baik pelaksanaan kepemimpinan transformasional berakibat pada peningkatan kinerja karyawan.

Mottoh (2015) menyatakan gaya kepemimpinan transformasional berpengaruh signifikan secara parsial terhadap kinerja karyawan. Penelitian dari Sanjiwani (2016) menyatakan bahwa kepemimpinan transformasional berpengaruh positif dan signifikan terhadap kinerja karyawan. Septyan et al. (2017) dan Maharani et al. (2013) yang menjelaskan adanya pengaruh positif dan signifikan antara gaya kepemimpinan transformasional dengan kinerja karyawan. Berdasarkan pemahaman tersebut dapat dirumuskan hipotesis pertama sebagai berikut.

$\mathrm{H}_{1}$ : Kepemimpinan transformasional berpengaruh positif dan signifikan terhadap kinerja karyawan.

Penelitian dari Atmojo (2012) dan Nur Insan et al. (2013) menyimpulkan kepemimpinan transformasional memiliki pengaruh positif dan signifikan pada kepuasan kerja. Zahari \& Subarghi (2012) menyatakan ada hubungan yang positif dan signifikan antara gaya kepemimpinan transformasional terhadap kepuasan kerja karyawan. Penelitian dari Al-Swidi et al. (2012) menyatakan bahwa kepemimpinan transformasional telah terbukti memiliki efek signifikan pada 
kepuasan kerja karyawan melalui peningkatan persepsi pemberdayaan karyawan. Dari pemahaman tersebut dapat dirumusakan hipotesis kedua sebagai berikut.

$\mathrm{H}_{2}$ : Kepemimpinan transformasional berpengaruh positif dan signifikan terhadap kepuasan kerja.

Anthony et al. (2006) menyatakan bahwa kepuasan kerja berpengaruh positif dan signifikan terhadap kinerja karyawan. Menurut Fadhil \& Mayowan (2018) pengaruh kepuasan kerja terhadap kinerja karyawan adalah tinggi rendahnya tingkat kepuasan kerja karyawan yang dirasakan akan mempengaruhi kinerja karyawan. Apabila kepuasan kerja tercapai maka kinerja karyawan atas organisasi tinggi. Hal ini terbukti dari hasil penelitian yang dilakukan oleh Changgriawan (2017) menyatakan kepuasan kerja berpengaruh signifikan terhadap kinerja karyawan.

Penelitian dari Arthawan (2017) menyatakan kepuasan kerja berpengaruh positif dan signifikan terhadap kinerja karyawan. Thamrin (2012) menyatakan kepuasan kerja berpengaruh positif dan signifikan terhadap kinerja karyawan. Fauzi et al. (2016) menyatakan ada pengaruh positif yang signifikan antara kepuasan kerja terhadap kinerja karyawan. Dari pemahaman tersebut dapat dirumusakan hipotesis ketiga sebagai berikut.

H3: Kepuasan kerja berpengaruh positif dan signifikan terhadap kinerja karyawan.

Menurut penelitian Shafie et al. (2013), Paracha et al. (2012) yang telah menemukan bahwa variabel kepuasan kerja berhasil menjadi variable mediasi antara variable endogen dan eksogen sejalan dengan penelitian yang dilakukan Lestari (2018) menyimpulkan kepuasan kerja mampu memediasi secara parsial gaya kepemimpinan transformasional terhadap kinerja karyawan. Hasil yang sama diperoleh penelitian dari Pambudi et al. (2016) menyatakan kepuasan kerja karyawan terbukti sebagai variabel mediasi dalam hubungan antara gaya kepemimpinan transformasional terhadap kinerja karyawan.

Penelitian yang dilakukan oleh Aulia et al. (2015) menyatakan gaya kepemimpinan transformasional berpengaruh secara signifikan terhadap kinerja karyawan melalui kepuasan kerja pada PDAM Kabupaten Bondowoso dan Nilasari et al. (2014) menyatakan kepemimpinan transformasional berpengaruh positif dan signifikan terhadap kinerja karyawan melalui kepuasan kerja Dinas Pendapatan Daerah Kabupaten Jember. Dari pemahaman tersebut dapat dirumusakan hipotesis keempat sebagai berikut.

$\mathrm{H}_{4}$ : Kepuasan kerja berpengaruh positif dan signifikan sebagai mediasi antara gaya kepemimpinan transformasional terhadap kinerja karyawan.

\section{METODE PENELITIAN}

Penelitian ini digolongkan ke dalam penelitian asosiatif untuk mengetahui hubungan dari satu variabel dengan variabel yang lainnya Variabel yang diteliti dalam penelitian ini yaitu peran mediasi kepuasan kerja pada gaya kepemimpinan transformasional terhadap kinerja karyawan Toyota Auto 2000 Denpasar.

Penelitian ini dilakukan di Toyota Auto 2000 Denpasar yang berlokasi Jalan Raya Cokroaminoto No.81, Pemecutan Kaja, Denpasar Utara, Kota Denpasar, Bali dipilih sebagai tempat penelitian karena terdapat permasalahan terkait dengan 
variabel gaya kepemimpinan transformasional, kepuasan kerja, dan kinerja karyawan.

Obyek dalam penelitian adalah gaya kepemimpinan transformasional, kepuasan kerja pada kinerja karyawan Toyota Auto 2000 Denpasar. Variabel endogen dalam penelitian ini adalah kinerja karyawan (Y). Variabel eksogen dalam penelitian ini adalah gaya kepemimpinan transformasional (X). Variabel mediasi dalam penelitian ini adalah kepuasan kerja (M).

Data kuantitatif adalah data berupa angka-angka. Data kuantitatif dalam penelitian ini adalah bobot skor kuesioner yang telah ditabulasikan dengan pembobotan jawaban responden yang terdiri dari data gaya kepemimpinan transformasional, kepuasan kerja dan kinerja karyawan di Toyota Auto 2000 Denpasar. Data kualitatif yang digunakan dalam penelitian ini adalah sejarah perusahaan, struktur organisasi dan aktivitas di Toyota Auto 2000 Denpasar.

Data primer adalah data yang diperoleh langsung dari sumbernya dan tanpa perantara. Data primer dalam penelitian ini adalah data penyebaran kuesioner kepada karyawan. Data sekunder adalah data yang dalam bentuk jadi yang diperoleh dari pihak lain yang telah mengumpulkan data tersebut seperti gambaran umum dari perusahaan yang diteliti. Instrumen yang digunakan dalam penelitian ini berupa kuesioner.

Populasi dalam penelitian ini adalah seluruh karyawan yang berjumlah 107 karyawan aktif tidak termasuk atasan pada Toyota Auto 2000 Denpasar. Pengambilan sampel dalam penelitian ini menggunakan metode sampel jenuh (sensus) yaitu seluruh karyawan sebanyak 107 orang yang bekerja pada Toyota Auto 2000 Denpasar. Pengumpulan data dalam penelitian ini dilakukan dengan menggunakan metode Wawancara dan Kuesioner

\section{HASIL DAN PEMBAHASAN}

Responden penelitian ini jika dilihat dari usia 26-30 Tahun dan 31-35 Tahun, hal ini dikarenakan usia yang paling mendominasi diantara yang lainnya serta termasuk usia produktif bekerja dan masa pensiun karyawan yaitu 45 Tahun. Jika di lihat dari karakteristik responden pada bagian jenis kelamin, responden di dominasi oleh laki-laki, hal ini dikarenakan pada saat rekruitmen karyawan yang paling dibutuhkan dalam bidangnya dan memenuhi persyaratan adalah laki-laki.

Sebagian besar responden dengan masa kerja 1-5 Tahun, hal ini dikarenakan perusahaan dengan teratur mengadakan rekruitmen karyawan, sehingga karyawan termasuk karyawan baru. Jika dilihat dari karakteristik responden pada bagian pendidikan, responden di dominasi oleh pendidikan Sarjana (S.1), hal ini dikarenakan dominan pada saat perekrutan yang dipilih adalah dengan tamatan sarjana dan sesuai pada bidangnya.

Hasil uji validitas menunjukkan bahwa seluruh instrumen penelitian yang digunakan untuk mengukur variabel gaya kepemimpinan transformasional, kepuasan kerja dan kinerja karyawan memiliki nilai koefisien korelasi dengan skor total seluruh item pernyataan lebih besar dari 0,3 . Hal ini menunjukkan bahwa butir-butir pernyataan dalam instrument penelitian tersebut valid dan layak digunakan sebagai instrument penelitian 
Tabel 1.

Rekapitulasi Hasil Uji Validitas Instrumen Penelitian

\begin{tabular}{ccccc}
\hline Variabel & Indikator & $\begin{array}{c}\text { Koefisien } \\
\text { Korelasi }\end{array}$ & $\begin{array}{c}\text { Koefisien } \\
\text { Batas }\end{array}$ & Keterangan \\
\hline \multirow{3}{*}{ Gaya Kepemimpinan } & $\mathrm{X}_{.1}$ & 0,893 & 0,3 & Valid \\
Transformasional (X) & $\mathrm{X}_{.2}$ & 0,876 & 0,3 & Valid \\
& $\mathrm{X}_{3}$ & 0,838 & 0,3 & Valid \\
& $\mathrm{X}_{.4}$ & 0,892 & 0,3 & Valid \\
& $\mathrm{M}_{1}$ & 0,775 & 0,3 & Valid \\
Kepuasan Kerja (M) & $\mathrm{M}_{2}$ & 0,852 & 0,3 & Valid \\
& $\mathrm{M}_{3}$ & 0,879 & 0,3 & Valid \\
& $\mathrm{M}_{4}$ & 0,883 & 0,3 & Valid \\
& $\mathrm{Y}_{1}$ & 0,696 & 0,3 & Valid \\
Kinerja Karyawan (Y) & $\mathrm{Y}_{2}$ & 0,755 & 0,3 & Valid \\
& $\mathrm{Y}_{3}$ & 0,886 & 0,3 & Valid \\
& $\mathrm{Y}_{4}$ & 0,778 & 0,3 & Valid \\
& $\mathrm{Y}_{5}$ & 0,826 & 0,3 & Valid \\
\hline
\end{tabular}

Sumber: Data Diolah, 2019

Tabel 2.

Rekapitulasi Hasil Uji Reliabilitas Instrumen Penelitian

\begin{tabular}{clcc}
\hline No. & \multicolumn{1}{c}{ Variabel } & Cronbach's Alpha & Keterangan \\
\hline 1. & Gaya Kepemimpinan Transformasional $(\mathrm{X})$ & 0,892 & Reliabel \\
3. & Kepuasan Kerja $(\mathrm{M})$ & 0,867 & Reliabel \\
4. & Kinerja Karyawan $(\mathrm{Y})$ & 0,849 & Reliabel \\
\hline
\end{tabular}

Sumber: Data Diolah, 2019

Hasil uji reliabilitas menunjukkan bahwa seluruh instrumen penelitian memiliki koefisien Cronbach's Alpha lebih dari 0,60. Jadi dapat dinyatakan bahwa seluruh variabel telah memenuhi syarat reliabilitas atau kehandalan sehingga dapat digunakan untuk melakukan penelitian.

Gaya kepemimpinan transformasional secara keseluruhan "Baik" hal ini dapat di lihat dari nilai rata-rata keseluruhan yaitu 3,82. Nilai rata-rata tertinggi pada pernyataan "Atasan saya memiliki pendirian yang kuat dalam memimpin perusahaan". Hal ini menunjukan atasan memiliki pendirian yang kuat dalam memimpin perusahaan.

Nilai rata-rata pada Tabel 3. terendah terdapat pada pernyataan "Atasan saya memberi dorongan dalam bekerja". Hal ini menunjukan bahwa atasan saya kurang maksimal memberi dorongan dalam bekerja. Pemberian dorongan dalam bekerja harusnya dimaksimalkan agar karyawan lebih baik kinerja dalam bekerja.

Secara keseluruhan pada Tabel 4. nilai rata-rata jawaban responden terhadap variabel kepuasan kerja memiliki nilai sebesar 3,96. Hasil penyebaran kuesioner menunjukkan bahwa pernyataan "Saya memiliki peluang yang sama dengan rekan kerja yang lain dalam promosi jabatan" memiliki nilai rata-rata tertinggi, hal ini berarti karyawan memiliki peluang yang sama dengan rekan kerja yang lain dalam 
promosi jabatan. Nilai rata-rata terendah terdapat pada pernyataan "Gaji yang saya terima sesuai dengan beban kerja”. Hal ini menunjukan bahwa gaji yang karyawan perlu lebih disesuaikan dengan bebak kerja karyawan sehingga bisa maksimal.

Tabel 3.

Deskripsi Jawaban Responden Terhadap Gaya Kepemimpinan Transformasional

\begin{tabular}{|c|c|c|c|c|c|c|c|c|}
\hline \multirow{2}{*}{ No. } & \multirow{2}{*}{ Pernyataan } & \multicolumn{5}{|c|}{ Frekuensi Jawaban Responden } & \multirow{2}{*}{$\begin{array}{l}\text { Rata- } \\
\text { Rata }\end{array}$} & \multirow{2}{*}{ Kriteria } \\
\hline & & STS & TS & $\mathrm{CS}$ & $\mathbf{S}$ & SS & & \\
\hline 1 & $\begin{array}{l}\text { Atasan saya memiliki } \\
\text { pendirian yang kuat dalam } \\
\text { memimpin perusahaan. }\end{array}$ & 0 & 3 & 36 & 24 & 44 & 4,02 & Baik \\
\hline 2 & $\begin{array}{l}\text { Atasan saya memberi } \\
\text { dorongan dalam bekerja. }\end{array}$ & 0 & 16 & 31 & 42 & 18 & 3,58 & Baik \\
\hline 3 & $\begin{array}{l}\text { Atasan saya memberi } \\
\text { kesempatan karyawan dalam } \\
\text { memberi masukan. }\end{array}$ & 0 & 12 & 27 & 44 & 24 & 3,75 & Baik \\
\hline \multirow[t]{2}{*}{4} & $\begin{array}{l}\text { Atasan saya mengajarkan } \\
\text { karyawan untuk bebas } \\
\text { berprestasi. }\end{array}$ & 0 & 2 & 35 & 37 & 33 & 3,94 & Baik \\
\hline & \multicolumn{6}{|c|}{$\begin{array}{c}\text { Rata-rata keseluruhan variabel gaya kepemimpinan } \\
\text { transformasional }\end{array}$} & 3,82 & Baik \\
\hline
\end{tabular}

Tabel 4.

Deskripsi Jawaban Responden Terhadap Variabel Kepuasan Kerja

\begin{tabular}{|c|c|c|c|c|c|c|c|c|}
\hline \multirow{2}{*}{ No } & \multirow{2}{*}{ Pernyataan } & \multicolumn{5}{|c|}{ Frekuensi Jawaban Responden } & \multirow{2}{*}{ Rata-Rata } & \multirow{2}{*}{ Kriteria } \\
\hline & & STS & TS & CS & $\mathbf{S}$ & SS & & \\
\hline 1 & $\begin{array}{l}\text { Saya merasa nyaman dalam } \\
\text { bekerja. }\end{array}$ & 0 & 7 & 28 & 32 & 40 & 3,98 & Puas \\
\hline 2 & $\begin{array}{l}\text { Gaji yang saya terima sesuai } \\
\text { dengan beban kerja. }\end{array}$ & 0 & 10 & 39 & 26 & 32 & 3,75 & Puas \\
\hline 3 & $\begin{array}{l}\text { Saya memiliki peluang yang } \\
\text { sama dengan rekan kerja } \\
\text { yang lain dalam promosi } \\
\text { jabatan. }\end{array}$ & 0 & 2 & 31 & 27 & 47 & 4,11 & Puas \\
\hline 4 & $\begin{array}{l}\text { Rekan kerja selalu } \\
\text { mendorong saya dalam } \\
\text { melaksanakan pekerjaan } \\
\text { dengan baik. }\end{array}$ & 0 & 3 & 34 & 28 & 42 & 4,02 & Puas \\
\hline & Rata-rata keseluruhan & ariabel & epua & n ke & & & 3,96 & Puas \\
\hline
\end{tabular}
Sumber: Data Diolah, 2019

Secara keseluruhan pada Tabel 5. nilai rata-rata jawaban responden terhadap variabel kinerja karyawan memiliki nilai sebesar 3,78. Hasil penyebaran kuesioner menunjukkan bahwa kinerja karyawan perusahaan "Baik". Nilai rata-rata tertinggi terdapat pada pernyataan "Saya bersungguh-sungguh dalam melaksanakan tugas yang diberikan". Hal ini menunjukan bahwa karyawan bersungguh-sungguh dalam melaksanakan tugas yang diberikan. 
Nilai rata-rata terendah terdapat pada pernyataan "Saya memiliki inisiatif menyelesaikan permasalahan dalam pekerjaan". Hal ini menunjukkan bahwa beberapa karyawan belum memiliki inisiatif menyelesaikan permasalahan dalam pekerjaan. Sehingga perlu adanya tindakan seperti perintah-perintah dari atasan untuk menyelesaikan persoalan yang ada.

\section{Tabel 5.}

Deskripsi Jawaban Responden Terhadap Variabel Kinerja Karyawan

\begin{tabular}{|c|c|c|c|c|c|c|c|c|}
\hline \multirow{2}{*}{ No } & \multirow{2}{*}{ Pernyataan } & \multicolumn{5}{|c|}{ Frekuensi Jawaban Responden } & \multirow{2}{*}{ Rata-Rata } & \multirow{2}{*}{ Kriteria } \\
\hline & & STS & TS & CS & $\mathbf{S}$ & SS & & \\
\hline 1 & $\begin{array}{l}\text { Saya memiliki } \\
\text { kemampuan dalam } \\
\text { menyelesaikan setiap } \\
\text { pekerjaan. }\end{array}$ & 0 & 4 & 48 & 29 & 26 & 3,72 & Baik \\
\hline 2 & $\begin{array}{l}\text { Saya bersungguh- } \\
\text { sungguh dalam } \\
\text { melaksanakan tugas } \\
\text { yang diberikan. }\end{array}$ & 0 & 2 & 33 & 30 & 42 & 4,05 & Baik \\
\hline 3 & $\begin{array}{l}\text { Saya memiliki inisiatif } \\
\text { menyelesaikan } \\
\text { permasalahan dalam } \\
\text { pekerjaan. }\end{array}$ & 0 & 13 & 37 & 28 & 29 & 3,68 & Baik \\
\hline 4 & $\begin{array}{l}\text { Saya taat dengan } \\
\text { peraturan perusahaan. } \\
\text { Saya memiliki }\end{array}$ & 0 & 11 & 38 & 30 & 28 & 3,70 & Baik \\
\hline 5 & kepedulian terhadap & 0 & 9 & 37 & 31 & 30 & 3,77 & Baik \\
\hline & Rata-rata keseluruha & varial & kin & ka & wan & & 3,78 & Baik \\
\hline
\end{tabular}
Sumber: Data Diolah, 2019

Tabel 6.

Hasil Uji Normalitas Struktur 1

\begin{tabular}{lc}
\hline & Unstandardized Residual \\
\hline $\mathrm{N}$ & 107 \\
Kolmogorov-Smirnov & 0,200 \\
\hline Sumber: Data Diolah, 2019 &
\end{tabular}

Nilai Kolmogorov Sminarnov (K-S) sebesar 0,200, hasil tersebut mengindikasikan bahwa model persamaan regresi tersebut berdistribusi normal karena nilai Kolmogorov-Smirnov lebih besar dari nilai alpha 0,05.

Tabel 7.

Hasil Uji Normalitas Struktur 2

\begin{tabular}{lc}
\hline & Unstandardized Residual \\
\hline $\mathrm{N}$ & 107 \\
Kolmogorov-Smirnov Z & 0,095 \\
\hline Sumber: Data Diolah, 2019
\end{tabular}


Nilai Kolmogorov Sminarnov Z (K-S) sebesar 0,095, hasil tersebut mengindikasikan bahwa model persamaan regresi tersebut berdistribusi normal karena nilai Kolmogorov-Smirnov lebih besar dari nilai alpha 0,05.

Tabel 8.

Hasil Uji Multikoleniaritas

\begin{tabular}{llcc}
\hline \multicolumn{1}{c}{ Persamaan Struktur } & \multicolumn{1}{c}{ Variabel } & Tolerance & VIF \\
\hline $\mathrm{M}=\beta_{1} \mathrm{X}+\mathrm{e}_{1}$ & $\begin{array}{l}\text { Gaya Kepemimpinan } \\
\text { Transformasional (X) }\end{array}$ & 1,000 & 1,000 \\
$\mathrm{Y}=\beta_{1} \mathrm{X}+\beta_{2} \mathrm{M}+\mathrm{e}_{2}$ & $\begin{array}{l}\text { Gaya Kepemimpinan } \\
\text { Transformasional (X) }\end{array}$ & 0,586 & 1,706 \\
& Kepuasan Kerja (M) & 0,586 & 1,706 \\
\hline
\end{tabular}

Sumber: Data Diolah, 2019

Nilai tolerance dan VIF dari variabel gaya kepemimpinan transformasional dan kepuasan kerja menunjukkan nilai tolerance untuk setiap variabel lebih besar dari 0,1 dan nilai VIF lebih kecil dari 10 yang berarti model persamaan regresi bebas dari multikolinearitas.

Tabel 9.

Hasil Uji Heteroskedastisitas Struktur 1

\begin{tabular}{|c|c|c|c|c|c|c|}
\hline \multicolumn{7}{|c|}{ Coefficients $^{a}$} \\
\hline \multirow{2}{*}{\multicolumn{2}{|c|}{ Model }} & \multicolumn{2}{|c|}{$\begin{array}{l}\text { Unstandardized } \\
\text { Coefficients }\end{array}$} & \multirow{2}{*}{$\begin{array}{c}\begin{array}{c}\text { Standardized } \\
\text { Coefficients }\end{array} \\
\text { Beta }\end{array}$} & \multirow[t]{2}{*}{$\mathbf{t}$} & \multirow[t]{2}{*}{ Sig. } \\
\hline & & B & Std. Error & & & \\
\hline \multirow[t]{2}{*}{1} & (Constant) & 2.066 & .688 & & 3.004 & .003 \\
\hline & $\begin{array}{l}\text { Gaya Kepemimpinan } \\
\text { Transformasional }\end{array}$ & -.038 & .044 & -.083 & -.856 & .394 \\
\hline
\end{tabular}

Sumber: Data Diolah, 2019

Nilai signifikansi dari variabel gaya kepemimpinan transformasional sebesar 0,394. Nilai tersebut lebih besar dari 0,05 yang berarti tidak terdapat pengaruh antara variabel bebas terhadap absolute residual. Dengan demikian, model yang dibuat tidak mengandung gejala heteroskedastisitas.

Nilai signifikansi dari variable gaya kepemimpinan transformasional dan kepuasan kerja, masing-masing sebesar 0,981 dan 0,325. Nilai tersebut lebih besar dari 0,05 yang berarti tidak terdapat pengaruh antara variabel bebas terhadap absolute residual. Dengan demikian, model yang dibuat tidak mengandung gejala heteroskedastisitas.

Nilai koefisien regresi variabel gaya kepemimpinan transformasional Pada Tabel 11. bernilai positif dengan nilai signifikansi uji t kurang dari 0,05 . Hal ini menunjukkan bahwa variabel gaya kepemimpinan transformasional memiliki pengaruh positif yang signifikan terhadap variabel kepuasan kerja. Besarnya pengaruh variabel bebas terhadap variabel terikat yang ditunjukkan oleh nilai determinasi total ( $R$ Square) sebesar 0,414 mempunyai arti bahwa sebesar 41,4 persen variasi kepuasan kerja dipengaruhi oleh variasi gaya kepemimpinan transformasional, sedangkan sisanya sebesar 58,6 persen dijelaskan oleh faktor lain yang tidak dimasukkan ke dalam model. 
Tabel 10.

Hasil Uji Heteroskedastisitas Struktur 2

\begin{tabular}{|c|c|c|c|c|c|c|}
\hline \multirow{3}{*}{\multicolumn{2}{|c|}{ Model }} & \multirow{2}{*}{\multicolumn{2}{|c|}{$\begin{array}{c}\text { Coefficients }^{\mathrm{a}} \\
\text { Unstandardized } \\
\text { Coefficients }\end{array}$}} & \multirow{3}{*}{$\begin{array}{c}\begin{array}{c}\text { Standardized } \\
\text { Coefficients }\end{array} \\
\text { Beta }\end{array}$} & \multirow{3}{*}{$\mathbf{t}$} & \multirow{3}{*}{ Sig. } \\
\hline & & & & & & \\
\hline & & B & Std. Error & & & \\
\hline \multirow[t]{3}{*}{1} & (Constant) & .530 & .832 & & .637 & .525 \\
\hline & Gaya Kepemimpinan & .002 & .062 & .003 & .024 & .981 \\
\hline & $\begin{array}{l}\text { Transformasional } \\
\text { Kepuasan Kerja } \\
\text { pendent Variable: AB }\end{array}$ & .062 & .063 & .126 & .989 & .325 \\
\hline
\end{tabular}

Sumber: Data Diolah, 2019

Tabel 11.

Hasil Analisis Jalur 1

\begin{tabular}{|c|c|c|c|c|c|}
\hline \multirow[t]{2}{*}{ Variabel } & \multicolumn{2}{|c|}{$\begin{array}{c}\text { Unstandardized } \\
\text { Coefficients }\end{array}$} & \multirow{2}{*}{$\begin{array}{c}\text { Standardized } \\
\text { Coefficients } \\
\text { Beta }\end{array}$} & \multirow{2}{*}{$\begin{array}{c}\text { t } \\
\text { hitun } \\
\mathrm{g}\end{array}$} & \multirow{2}{*}{$\begin{array}{l}\text { Sig. } \\
\text { uji t }\end{array}$} \\
\hline & B & Std. Error & & & \\
\hline (Constant) & 6.111 & 1.147 & & $\begin{array}{r}5.32 \\
8\end{array}$ & .000 \\
\hline $\begin{array}{l}\text { Gaya Kepemimpinan } \\
\text { Transformasional (X) }\end{array}$ & .638 & .074 & .643 & 8.60 & .000 \\
\hline R Square & 0,414 & & & & \\
\hline F Statistik & 74,086 & & & & \\
\hline Signifikansi Uji F & 0,000 & & & & \\
\hline
\end{tabular}

Sumber: Data Diolah, 2019

Tabel 12.

Hasil Analisis Jalur 2

\begin{tabular}{|c|c|c|c|c|c|}
\hline \multirow[t]{2}{*}{ Variabel } & \multicolumn{2}{|c|}{$\begin{array}{c}\text { Unstandardized } \\
\text { Coefficients }\end{array}$} & \multirow{2}{*}{$\begin{array}{c}\text { Standardized } \\
\text { Coefficients } \\
\text { Beta }\end{array}$} & \multirow{2}{*}{$\begin{array}{c}\mathbf{t} \\
\text { hitun } \\
\mathrm{g}\end{array}$} & \multirow{2}{*}{$\begin{array}{l}\text { Sig. } \\
\text { uji t }\end{array}$} \\
\hline & B & Std. Error & & & \\
\hline (Constant) & 4.377 & 1.364 & & $\begin{array}{r}3.21 \\
0\end{array}$ & .002 \\
\hline $\begin{array}{l}\text { Gaya Kepemimpinan } \\
\text { Transformasional (X) }\end{array}$ & .551 & . 102 & .473 & $\begin{array}{r}5.40 \\
1\end{array}$ & .000 \\
\hline Kepuasan Kerja (M) & .385 & .103 & .328 & $\begin{array}{r}3.74 \\
4\end{array}$ & .000 \\
\hline $\begin{array}{l}\text { R Square } \\
\text { F Statistik } \\
\text { Sionifikansi }\end{array}$ & $\begin{array}{c}0,532 \\
59,014\end{array}$ & & & & \\
\hline
\end{tabular}

Sumber: Data Diolah, 2019

Nilai koefisien regresi masing-masing variabel bebas bernilai positif dengan nilai signifikansi uji t kurang dari 0,05 . Hal ini menunjukkan bahwa semua variabel bebas memiliki pengaruh positif yang signifikan terhadap variabel terikat. Besarnya pengaruh variabel bebas terhadap variabel terikat yang ditunjukkan oleh nilai determinasi total ( $R$ Square) sebesar 0,532 mempunyai arti bahwa sebesar 53,2 persen variasi kinerja karyawan dipengaruhi oleh variasi gaya kepemimpinan transformasional dan kepuasan kerja, sedangkan sisanya sebesar 46,8 persen dijelaskan oleh faktor lain yang tidak dimasukkan ke dalam model. 
Hasil dari perhitungan pengaruh error (Pei), didapatkan hasil pengaruh error $\left(\mathrm{Pe}_{1}\right)$ sebesar 0,910 dan pengaruh error $\left(\mathrm{Pe}_{2}\right)$ sebesar 0,847.

Nilai determinasi total sebesar 0,406 mempunyai arti bahwa sebesar 40,6 persen variasi kinerja karyawan dipengaruhi oleh variasi gaya kepemimpinan transformasional dan kepuasan kerja, sedangkan sisanya sebesar 59,4 persen dijelaskan oleh faktor lain yang tidak dimasukkan ke dalam model.

Hasil analisis dari pengaruh gaya kepemimpinan transformasional terhadap kepuasan kerja diperoleh nilai signifikansi sebesar 0,000 dengan nilai koefisien beta 0,643 bernilai positif. Nilai signifikansi $0,000<0,05$ mengindikasikan bahwa $\mathrm{H}_{0}$ ditolak dan $\mathrm{H}_{1}$ diterima. Hasil ini mempunyai arti bahwa gaya kepemimpinan transformasional berpengaruh positif dan signifikan terhadap kepuasan kerja.

Hasil analisis dari pengaruh gaya kepemimpinan transformasional terhadap kinerja karyawan diperoleh nilai signifikansi sebesar 0,000 dengan nilai koefisien beta 0,473 bernilai positif. Nilai signifikansi $0,000<0,05$ mengindikasikan bahwa $\mathrm{H}_{0}$ ditolak dan $\mathrm{H}_{2}$ diterima. Hasil ini mempunyai arti bahwa gaya kepemimpinan transformasional berpengaruh positif dan signifikan terhadap kinerja karyawan.

Hasil analisis dari pengaruh kepuasan kerja terhadap kinerja karyawan diperoleh nilai signifikansi sebesar 0,000 dengan nilai koefisien beta 0,328 bernilai positif. Nilai signifikansi $0,000<0,05$ mengindikasikan bahwa $\mathrm{H}_{0}$ ditolak dan $\mathrm{H}_{3}$ diterima. Hasil ini mempunyai arti bahwa kepuasan kerja berpengaruh positif dan signifikan terhadap kinerja karyawan.

Tabel 13.

Pengaruh Langsung dan Pengaruh Tidak Langsung serta Pengaruh Total Gaya Kepemimpinan Transformasional (X), Kepuasan Kerja (M), Kinerja Karyawan (Y)

\begin{tabular}{cccc}
\hline $\begin{array}{c}\text { Pengaruh } \\
\text { Variabel }\end{array}$ & $\begin{array}{c}\text { Pengaruh } \\
\text { Langsung }\end{array}$ & $\begin{array}{c}\text { Pengaruh Tidak Langsung Melalui } \\
\text { Perceived Value } \\
(\text { Y1 })(\boldsymbol{\beta} 1 \text { x } \boldsymbol{\beta 3})\end{array}$ & Pengaruh Total \\
\hline $\mathrm{X} \rightarrow \mathrm{M}$ & 0,643 & - & 0,643 \\
$\mathrm{X} \rightarrow \mathrm{Y}$ & 0,473 & 0,211 & 0,684 \\
$\mathrm{M} \rightarrow \mathrm{Y}$ & 0,328 & - & 0,328 \\
\hline
\end{tabular}

Sumber: Data Diolah, 2019

Pengaruh langsung gaya kepemimpinan transformasional terhadap kepuasan kerja adalah sebesar 0,643. Pengaruh langsung variabel gaya kepemimpinan transformasional terhadap kinerja karyawan sebesar 0,473. Pengaruh langsung variabel kepuasan kerja terhadap kinerja karyawan sebesar 0,328. Hal ini berarti bahwa variabel kinerja karyawan lebih besar dipengaruhi oleh kepuasan kerja dari gaya kepemimpinan transformasional. Sedangkan pengaruh tidak langsung variabel gaya kepemimpinan transformasional terhadap kinerja karyawan melalui kepuasan kerja sebesar 0,211. Jadi pengaruh total variabel gaya kepemimpinan transformasional terhadap kinerja karyawan melalui kepuasan kerja adalah sebesar 0,684 . Jadi dapat dinyatakan bahwa lebih besar total pengaruh gaya kepemimpinan transformasional terhadap kinerja karyawan yang melalui kepuasan kerja dari pada 
pengaruh langsung gaya kepemimpinan transformasional terhadap kinerja karyawan tanpa melalui variabel kepuasan kerja.

Hasil analisis data menunjukkan bahwa gaya kepemimpinan transformasional secara keseluruhan baik hal ini dapat di lihat dari keseluruhan rata-rata gaya kepemimpinan transformasional yaitu 3,82. Nilai rata-rata tertinggi pada pernyataan "Atasan saya memiliki pendirian yang kuat dalam memimpin perusahaan". Hal ini menunjukan atasan memiliki pendirian yang kuat dalam memimpin perusahaan. Selain itu, nilai rata-rata terendah terdapat pada pernyataan "Atasan saya memberi dorongan dalam bekerja". Hal ini menunjukan bahwa atasan karyawan kurang maksimal memberi dorongan dalam bekerja. Pemberian dorongan atau motivasi dalam bekerja harusnya dioptimalkan agar karyawan lebih baik kinerja dalam bekerja.

Hasil analisis data menunjukan bahwa analisis pengaruh gaya kepemimpinan transformasional terhadap kinerja karyawan diperoleh nilai signifikansi sebesar 0,000 dengan nilai koefisien beta 0,473 bernilai positif. Nilai signifikansi $0,000<$ 0,05 mengindikasikan bahwa $\mathrm{H}_{0}$ ditolak dan $\mathrm{H}_{1}$ diterima. Hasil ini mengindikasikan bahwa gaya kepemimpinan transformasional berpengaruh positif dan signifikan terhadap kinerja karyawan.

Gaya kepemimpinan transformasional adalah kepemimpinan sejati, dimana seorang pemimpin memberikan motivasi kepada bawahannya untuk bekerja secara maksimal agar tujuan perusahaan tercapai. Berdasarkan pemaparan tersebut tujuan perusahaan akan tercapai jika karyawan memiliki kinerja yang optimal. Sehingga untuk mengoptimalkan kinerja karyawan, atasan perusahaan hendaknya memiliki gaya kepemimpinan transformasional. Selain itu, hal senada juga diungkapkan oleh Ruyatnasih et al. (2013) menyatakan bahwa gaya kepemimpinan berpengaruh positif dan signifikan terhadap kinerja karyawan. Penelitian yang dilakukan oleh Suharnomo \& Subakti (2013) menyatakan kepemimpinan transformasional dapat mempengaruhi variabel kinerja karyawan. Dengan demikian dapat dinyatakan terdapat pengaruh gaya kepemimpinan transformasional yang positif dan signifikan terhadap kinerja karyawan.

Hasil analisisi data menunjukan bahwa gaya kepemimpinan transformasional secara keseluruhan baik hal ini dapat dilihat dari nilai keseluruhan rata-rata variabel gaya kepemimpinan transformasional yaitu 3,82. Nilai rata-rata tertinggi pada pernyataan "Atasan saya memiliki pendirian yang kuat dalam memimpin perusahaan". Hal ini menunjukan atasan memiliki pendirian yang kuat dalam memimpin perusahaan. Selain itu, nilai rata-rata terendah terdapat pada pernyataan "Atasan saya memberi dorongan dalam bekerja". Hal ini menunjukan bahwa atasan karyawan kurang maksimal memberi dorongan dalam bekerja. Pemberian dorongan atau motivasi dalam bekerja harusnya dioptimalkan agar karyawan lebih baik kinerja dalam bekerja.

Hasil analisis pengaruh gaya kepemimpinan transformasional terhadap kepuasan kerja diperoleh nilai signifikansi sebesar 0,000 dengan nilai koefisien beta 0,643 bernilai positif. Nilai signifikansi $0,000<0,05$ mengindikasikan bahwa $\mathrm{H}_{0}$ ditolak dan $\mathrm{H}_{2}$ diterima. Sehingga hasil ini mempunyai arti bahwa gaya kepemimpinan transformasional berpengaruh positif dan signifikan terhadap kepuasan kerja. 
Gaya kepemimpinan transformasional adalah kepemimpinan sejati, dimana seorang pemimpin memberikan motivasi kepada bawahannya untuk bekerja secara maksimal agar tercapai tujuan perusahaan. Sedangkan kepuasan kerja adalah penilaian dari seberapa jauh pekerjaan yang dijalankan secara keseluruhan memuaskan kebutuhannya. Dengan adanya gaya kepemimpinan transformasional yang mampu memotivasi karyawan hingga mampu bekerja maksimal maka kepuasan kerja karyawan akan tinggi juga. Hal tersebut terjadi karena karyawan yang termotivasi oleh gaya kepemimpinan tranformasional akan memiliki standar kepuasan kerja yang tinggi.

Kepuasan kerja yang tinggi karyawan akan memiliki kualitas kinerja yang tinggi. Hal tersebut senada dengan penelitian yang dilakukan oleh Atmojo (2012) dan Nur Insan et al. (2013) menyimpulkan kepemimpinan transformasional memiliki pengaruh positif dan signifikan pada kepuasan kerja. Selain itu hal senada juga diungkapkan oleh Zahari \& Subarghi (2012) menyatakan ada hubungan yang positif dan signifikan antara gaya kepemimpinan transformasional terhadap kepuasan kerja karyawan. Penelitian dari Al-Swidi et al. (2012) menyatakan bahwa kepemimpinan transformasional telah terbukti memiliki efek signifikan pada kepuasan kerja karyawan melalui peningkatan persepsi pemberdayaan karyawan. Dengan demikian dapat dinyatakan bahwa ada hubungan yang positif dan signifikan antara gaya kepemimpinan transformasional terhadap kepuasan kerja.

Hasil analisis data menunjukkan bahwa keseluruhan rata-rata jawaban responden terhadap variabel kepuasan kerja memiliki nilai sebesar 3,96. Hasil penyebaran kuesioner menunjukkan bahwa pernyataan "Saya memiliki peluang yang sama dengan rekan kerja yang lain dalam promosi jabatan" memiliki nilai rata-rata paling tinggi, hal ini berarti karyawan memiliki peluang yang sama dengan rekan kerja yang lain dalam promosi jabatan. Sedangkan nilai rata-rata terendah terdapat pada pernyataan "Gaji yang saya terima sesuai dengan beban kerja". Hal ini menunjukan bahwa gaji yang karyawan perlu lebih disesuaikan dengan beban kerja karyawan sehingga kinerja karyawan maksimal.

Hasil analisis data diperoleh bahwa pengaruh kepuasan kerja terhadap kinerja karyawan diperoleh nilai signifikansi sebesar 0,000 dengan nilai koefisien beta 0,328 bernilai positif. Nilai signifikansi $0,000<0,05$ mengindikasikan bahwa $\mathrm{H}_{0}$ ditolak dan $\mathrm{H}_{3}$ diterima. Hasil ini mempunyai arti bahwa kepuasan kerja berpengaruh positif dan signifikan terhadap kinerja karyawan.

Kepuasan kerja adalah penilaian dari seberapa jauh pekerjaan yang dijalankan secara keseluruhan memuaskan kebutuhannya. Kepuasan kerja juga adalah sikap umum yang merupakan hasil dari beberapa sikap khusus terhadap faktor-faktor pekerjaan, penyesuaian diri dan hubungan sosial individu di luar kerja. Individu yang memiliki kualitas kepuasan kerja yang tinggi akan memiliki kualitas kinerja yang tinggi juga. Hal tersebut terjadi karena semakin tinggi kepuasan kerja individu maka penilaian individu terhadap suatu pekerjaan tentu akan tinggi, maka untuk memenuhi standar penilaian tersebut karyawan akan meningkatkan standar kinerjanya sehingga kepuasan kerja akan terpenuhi. Pemaparan tersebut sesuai dengan penelitian yang dilakukan oleh Anthony et al. (2006) menyatakan bahwa kepuasan kerja berpengaruh positif dan signifikan terhadap kinerja karyawan. Menurut Fadhil \& Mayowan (2018) pengaruh kepuasan kerja terhadap kinerja 
karyawan adalah tinggi rendahnya tingkat kepuasan kerja karyawan yang dirasakan akan mempengaruhi kinerja karyawan. Dengan demikian dapat dinyatakan bahwa terdapat pengaruh positif dan signifikan kepuasan kerja terhadap kinerja karyawan.

Hasil analisis data didapat nilai $\mathrm{Z}$ hitung sebesar 7,349>1,96. Artinya kepuasan kerja berpengaruh positif dan signifikan sebagai mediasi antara gaya kepemimpinan transformasional terhadap kinerja karyawan. Selain itu, nilai VAF sebesar 26,4\% yaitu lebih dari 20\%, maka dapat dijelaskan bahwa ada efek mediasi atau dengan kata lain kepuasan kerja sebagai pemediasi parsial (partial mediation) yang dimana hasil pemeriksaan uji mediasi telah menunjukkan bahwa sesuai dengan kriteria pengaruh variabel eksogen terhadap variabel mediasi $0,000<0,05$ adalah signifikan, pengaruh variabel mediasi terhadap varibel endogen $0,000<0,05$ adalah signifikan, pengaruh langsung variabel eksogen terhadap variabel endogen pada model dengan melibatkan variabel mediasi $0,000<0,05$ adalah signifikan, maka dapat dikatakan sebagai partial mediation.

Gaya kepemimpinan transformasional dapat memberikan dorongan serta motivasi sehingga kualitas kepuasan kerja meningkat. Kualitas kepuasan kerja yang tinggi akan memberikan standar kinerja yang tinggi pada karyawan. Dengan demikian dapat dinyatakan bahwa kepuasan kerja berpengaruh positif dan signifikan sebagai mediasi antara gaya kepemimpinan transformasional terhadap kinerja karyawan.

Hasil penelitian yang dilakukan ini menunjukkan bahwa ada hubungan yang positif dan signifikan antara gaya kepemimpinan transformasional yang positif dan signifikan terhadap kinerja karyawan, terdapat pengaruh gaya kepemimpinan transformasional terhadap kepuasan kerja, terdapat pengaruh positif dan signifikan kepuasan kerja terhadap kinerja karyawan, serta kepuasan kerja berpengaruh positif dan signifikan sebagai mediasi antara gaya kepemimpinan transformasional terhadap kinerja karyawan. Berdasarkan tema tersebut, didapatkan hasil penelitian ini mampu memperkaya pengembangan ilmu manajemen sumber daya manusia khususnya terkait aspek kinerja karyawan dan mendukung studi-studi empiris lainnya terkait dengan pengaruh gaya kepemimpinan transformasiona terhadap kinerja karyawan, gaya kepemimpinan tansformasional terhadap kepuasan kerja, kepuasan kerja terhadap kinerja karyawan, dan peran kepuasan kerja sebagai mediasi pada gaya kepemimpinan transformasioal terhadap kinerja karyawan.

Kinerja merupakan hasil kerja karyawan yang dijalankan sehingga tercapai dari tujuan perusahaan dengan waktu yang sudah ditentukan sebelumnya. Karyawan yang memiliki kinerja yang baik tentu akan mengakibatkan perusahaan menjadi lebih maju. Hal tersebut melatarbelakangi alasan agar perusahaan hendaknya fokus pada usaha dalam meningkatkan kualitas kinerja karyawan.

Gaya kepemimpinan transformasional merupakan faktor yang penting dalam memberikan andil dalam kinerja karyawan. Hal tersebut berimplikasi pada tindakan yang hendaknya diambil oleh pihak manajemen dalam rangka meningkatkan kinerja karyawan. Berdasarkan asumsi tersebut untuk meningkatkan kualitas kinerja karyawan, pihak manajemen dapat mempertimbangkan gaya kepemimpinan sebagai salah satu faktor yang perlu dioptimalkan.

Kepuasan kerja menjadi faktor yang memberikan pengaruh terhadap kinerja karyawan. Pernyataan tersebut tentu berimplikasi terhadap upaya peningkatan 
kinerja karyawan oleh pihak manajeman melalui pengoptimalan kepuasan kerja. Hal tersebut dapat dilakukan dengan memberikan diklat dan peningkatan standar kerja sehingga kinerja karyawan meningkat.

Kinerja karyawan merupakan hasil dari kegiatan kerja yang dilakukan oleh karyawan guna mencapai tujuan perusahaan. Hal ini mengindikasikan bahwa pihak manajemen perlu mengambil tindakan yang terkait dengan usaha meningkatkan kinerja karyawan. Dengan demikian tujuan perusaahaan akan tercapai.

Penelitian yang telah dilakukan, terdapat beberapa keterbatasan dalam penelitian ini, yaitu Faktor-faktor yang memengaruhi kinerja karyawan dalam penelitian ini hanya terdiri dari 2 variabel yaitu gaya kepemimpinan transformasional dan kepuasan kerja sedangkan masih terdapat faktor lain yang belum dimasukan dalam penelitian. Dengan demikian perlu dilakukan replikasi penelitian dengan menambahkan variabel lain yang berpeluang memiliki pengaruh terhadap kinerja karyawan serta merekontruksi kerangka berpikir agar lebih mengambarkan keadaan sebenarnya.

Penggunaan kuesioner memberikan dampak negative berupa kemungkinan data yang didapat tidak sesuai dengan keadaan yang sebenarnya. Hal tersebut terjadi karena responden hanya memberikan respon sesuai butir yang disediakan tanpa berkesempatan memberikan tanggapan lain. Dengan demikian perlu ditambahkan kegiatan observasi dan dokumentasi dalam mengumpulkan data tambahan untuk melakukan triangulasi.

Penggunaan sampel dengan jumlah terbatas memberikan pengaruh terhadap akurasi hasil penelitian. Hal tersebut akan mempengaruhi generalisasi hasil terhadap populasi keseluruhan. Dengan demikian perlu dilakukan replikasi penelitian dengan menambah sampel penelitian.

\section{SIMPULAN}

Simpulan dari penelitian ini adalah Gaya kepemimpinan transformasional berpengaruh positif dan signifikan terhadap kinerja karyawan. Hal ini menunjukan bahwa jika gaya kepemimpinan transformasional semakin meningkat maka akan meningkatkan pula kinerja karyawan. Gaya kepemimpinan transformasional berpengaruh positif dan signifikan terhadap kepuasan kerja. Hal ini menunjukan bahwa jika gaya kepemimpinan transformasional semakin meningkat maka akan meningkatkan pula kepuasan kerja.

Kepuasan kerja berpengaruh positif dan signifikan terhadap kinerja karyawan. Hal ini menunjukan bahwa jika kepuasan kerja semakin meningkat maka akan meningkatkan pula kinerja karyawan. Kepuasan kerja secara positif dan signifikan memediasi pengaruh gaya kepemimpinan transformasional terhadap kinerja karyawan. Hal ini menunjukan bahwa gaya kepemimpinan transformasional memberikan dampak yang signifikan terhadap kinerja karyawan jika di mediasi oleh kepuasan kerja, yang berarti bahwa kinerja karyawan sangat tergantung pada tingkat kepuasan kerja tersebut dan juga tingkat gaya kepemimpinan transformasional. Saran yang dapat disampaikan sehingga nantinya dipergunakan sebagai bahan pertimbangan dalam menentukan kebijakan terkait kinerja karyawan Toyota Auto 2000 Denpasar 
dimasa mendatang yaitu Management Toyota Auto 2000 Denpasar hendaknya pada atasan dapat memberikan dorongan dalam bekerja harus dimaksimalkan agar karyawan lebih baik kinerjanya dalam bekerja, seperti: memberikan penghargaan/Reward, perhatian, dan memberi dorongan kepada karyawan untuk terus belajar dan berkembang. Dengan demikian prestasi kinerja karyawan akan meningkat. Management Toyota Auto 2000 Denpasar diharapkan dapat memaksimalkan gaji yang diterima oleh karyawan disesuaikan dengan beban kerja karyawan, seperti: bonus, hadiah dan lain-lain. Dengan demikian karyawan merasa puas dan nyaman dalam bekerja.

Management Toyota Auto 2000 Denpasar hendaknya memberikan insiatif kepada beberapa karyawan dalam menyelesaikan permasalahan dalam pekerjaan, seperti: memberikan pelatihan secara rutin dan berkala. Sehingga tidak menunggu perintah-perintah dari atasan untuk menyelesaikan persoalan yang ada. Management Toyota Auto 2000 Denpasar dapat mengoptimalkan gaya kepemimpinan tranformasional yang dapat memberikan andil pada kepuasan kerja melalui kebijakan-kebijakan terntentu. Dengan demikian kinerja karyawan akan optimal.

\section{REFERENSI}

Al-Swidi, A. ., Nawawi, M. ., \& Al-Hosam, A. (2012). Is the Relationship Between Employees "Psychological Empowerment and Employees" Job Satisfaction Contingent on the Transformational Leadership: A Study on the Yemeni Islamic Banks. Journal Asian Social Science, 8(10), 130-150.

Anthony, S., Hug, G., Simoens, S., Bojke, C., \& Sibbald, B. (2006). Job Satisfaction and Quitting Intentions: A Structural Model of British General Practitioners. British Journal of Industrial Relations, 44(3), 519-540.

Ardana, K., Mujiati, N. W., \& Utama, I. W. M. (2012). Manajemen Sumber Daya Manusia (Edisi Pert). Yogyakarta: Graha ilmu.

Arthawan, K. J. (2017). Pengaruh Gaya Kepemimpinan Transformasional dan Kepuasan Kerja Terhadap Kinerja Karyawan Pada LPD Kesiman Di Denpasar. E-Jurnal Manajemen Unud, 6(3), 1221-1247.

Atmojo, M. (2012). The Influence of Transformational Leadership on Job Satisfaction, Organizational Commitment, and Employee Performance. International Research Journal of Business Studies, 5(2), 113-128.

Aulia, N. L., Utami, W., \& Krishnabudi, N. G. (2015). Pengaruh Gaya Kepemimpinan Transformasional dan Lingkungan Kerja Terhadap Kinerja Karyawan Melalui Kepuasan Kerja Sebagai Variabel Intervening Pada PDAM Kabupaten Bondowoso. Jurnal Artikel Ilmiah, 1(8), 1-10.

Cemal, Z., Muceldili, B., \& Sehir, S. (2012). The Moderating Effect of Ethical Climate on the Relationship Between Job Satisfaction and Organizational 
Commitment: Evidence from Large Companies in Turkey. Journal Social and Behavioral Sciences, 5(8), 734-743.

Changgriawan, G. S. (2017). Pengaruh Kepuasan Kerja Dan Motivasi Kerja Terhadap Kinerja Karyawan di One Way Production. Jurnal AGORA, 5(3), 17.

Dwipayana, I. M. G. (2016). Analisis Faktor-faktor yang Mempengaruhi Kinerja Pegawai Pada PT. Karang Bali Asli Tour. E-Jurnal Manajemen Unud, 5(3), 1542-1571.

Fadhil, A., \& Mayowan, Y. (2018). Pengaruh Motivasi Kerja dan Kepuasan Kerja Terhadap Kinerja Karyawan Ajb Bumiputera. Jurnal Administrasi Bisnis (JAB), 54(1), 40-47.

Fauzi, M., Warso, M. M., \& Haryono, A. T. (2016). Pengaruh Budaya Organisasi dan Kepuasan Kerja Terhadap Kinerja Karyawan Dengan Komitmen Organisasi Sebagai Variabel Intervening (Studi Pada Karyawan PT. Toys Games Indonesia Semarang). Journal of Management, 2(2), 1-15.

Gupta, A. (2013). Relationship Between Entrepreneuirial Personality Between Entrepreneurial Personality, Performance, Job Statistification and Operations Strategy: An Empirical Examination. International Journal Of Business and Management, 8(2), 387-393.

Iskandar. (2016). Implementasi Teori Hirarki Kebutuhan Abraham Maslom terhadap Peningkatan Kinerja Pustakawan. Jurnal Ilmu Perpustakaan, Informasi, Dan Kearsipan Khizanah Al-Hikmah, 4(1), 24-34.

Lestari, A. N. (2018). Pengaruh Gaya Kepemimpinan Transformasional Dan Budaya Organisasi Terhadap Kinerja Karyawan Melalui Kepuasan Kerja Sebagai Variabel Interverning (Studi pada PT The Univenus, Kragilan Serang Tahun 2018). Tirtayasa Ekonomika, 10(2), 274-299.

Maharani, V., Eka, A. ., \& Noermijati. (2013). Organizational Citizenship Behavior Role in Mediating the Effect of Transformational Leadership, Job Satisfaction on Employee Performance: Studies in PT. Bank Syariah Mandiri Malang East Java. International Journal of Business and Management, 8(17), 1833-3850.

Mottoh, S. N. (2015). The Influence Of Transformational And Transactional Leadership Style On Employee Performance (case study: Dinas Kesehatan Manado). Jurnal Berkala Ilmiah Efisiensi, 15(4), 436-446.

Muizu, W. O. Z. (2014). Pengaruh Kepemimpinan Terhadap Kinerja Karyawan. Pekbis Jurnal, 6(1), 1-13. 
Nilasari, S., Titisari, P., \& Prajitiasari, E. D. (2014). Pengaruh Kepemimpinan Transformasional Dan Penilaian Kinerja Terhadap Kinerja Melalui Kepuasan Kerja Karyawan Dinas Pendapatan Daerah Kabupaten Jember. Jurnal Artikel Ilmiah, 1(7), 1-6.

Nur Insan, A., Astuti, E. S., Raharjo, K., \& Hamid, D. (2013). The Effect of Transformational Leadership Model on Employees Job Satisfaction and Performance at Perusahaan Listrik Negara (PLN Persero) in South Sulawesi, Indonesia. Jurnal Information and Knowledge Management, 3(5), 135-142.

Pambudi, D. S., Mukzam, D., \& Nurtjahjono, G. E. (2016). Pengaruh Gaya Kepemimpinan Transformasional Terhadap Kinerja Karyawan Melalui Kepuasan Kerja Karyawan Sebagai Variabel Mediasi (Studi Pada Karyawan PT Telkom Indonesia Witel Jatim Selatan Malang). Jurnal Administrasi Bisnis, 39(1), 164-171.

Paracha, M. U., Qamar, A., Mirza, A., Hassan-I-U, \& Waqus, H. (2012). Impact of Leadership Style (transformational and transactional) on Employee Performance and Mediating Role of Job Satisfaction, Study of Private School (Educator) in Pakistan. Global Journal of Management and Business Reasearch, 12(4), 55-64.

Rosario, G.-G. (2012). Study on The Job Satisfaction of Graduates and Received Training in The University. Journal Social and Behavioral Sciences, 2(8), 526-529.

Ruyatnasih, H.., Musadad, H.., \& Hasyim, B. (2013). Pengaruh Gaya Kepemimpinan Terhadap Kinerja Karyawan Pada Bagian Operator SPBU PT. Mitrabuana Jayalestari Karawang. Jurnal Manajemen, 10(3), 1106-1116.

Samaneh, A., Kiamanesh, A. R., \& Ebrahim, A. N. (2012). Emotional Intelligence and Organizational Commitment: Testing the Mediatory Role of Occupational Stress and Job Satisfaction. International Education and Educational Psychology Journal, 2(9), 1965-1976.

Sanjiwani, A. (2016). Pengaruh Kepemimpinan Transformasional, Kepuasan Kerja Dan Komitmen Organisasi Terhadap Kinerja Karyawan Bagus Hayden Hotel Kuta, Bali. Jurnal Manajemen Unud, 5(2), 1131-1159.

Septyan, F. B., Musadieq, M. Al, \& Mukzam, M. D. (2017). Pengaruh Gaya Kepemimpinan Transformasional Terhadap Motivasi dan Kinerja (Studi Pada Karyawan CV. Jade Indopratama Malang). Jurnal Administrasi Bisnis, 53(1), $81-88$.

Shafie, B., Baghersalimi, S., \& Barghi, V. (2013). The Relationship Between Leadership Style and Employee Performance, Case Study of Real Estate 
Registraion Organisation of Tehran Province. Singaporean Journal of Business Economics and Management Studies, 2(5), 21-29.

Simamora, H. (2008). Manajemen Sumber Daya Manusia. Jakarta: Bagian Penerbit STIE YKPN.

Suharnomo, M., \& Subakti, P. (2013). Pengaruh Kepemimpinan Transformasional dan Motivasi Terhadap Kinerja Karyawan (Study Pada PT. Kereta Api Indonesia Daop IV Semarang). Diponegoro Journal of Management, 2(3), 18 .

Thamrin, H. M. (2012). The Influence of Transformational Leadership and Organizational Commitment on Job Satisfaction and Employee Performance. International Journal of Innovation, Management and Technology, 3(5), 566572.

Tugba, D., \& Tabancali, E. (2012). The Relationship Between Organizational Justice Perceptions and Job Satisfaction Levels. Journal Social and Behavioral Sciences, 4(6), 5777-5781.

Yusuf, H. T. (2014). Pengaruh Kepemimpinan, Komunikasi, Motivasi Kerja dan Kedisiplinan Terhadap Kinerja Karyawan PT. Komatsu Remanufacturing Asia Plant Sudirman di Departemen Produksi Balikpapan. Journal Ilmu Ekonomi \& Manajemen, 10(1), 49-58.

Zahari, I. ., \& Subarghi, A. M. . (2012). The Effect Organizational Culture and The Relationship Between Transformational Leadership and Job in Petrolium Sector of Libya. International Business Research, 5(9), 89-97. 